\title{
Analysis of Audience Response to Public Service Advertisement about Covid-19 in Instagram
}

\author{
Sylvie Nurfebiaraning ${ }^{1 *}$ Lu'lu Mutia $^{2}$ \\ ${ }^{1,2}$ School of Communication and Business, Telkom University, Bandung Indonesia \\ *Corresponding author, Email: sylvienurfebia@telkomuniversity.ac.id
}

\begin{abstract}
COVID-19 pandemic has taken place globally, especially in Indonesia, so the government has decided to prevent the spread of the corona virus. One of them is the Ministry of Health of Republic of Indonesia, as a government institution that has been recognized and accepted, and has certain impacts and interests. This is explained in Permenkes 64 of 2016, the 3rd clause which carries out functions, one of which is the implementation of policies in the field of public health, prevention and control of diseases. Through advertising that consists of visuals and texts in infographics, the Ministry of Health of Republic of Indonesia informs and persuades the audience in the early prevention of the corona virus in Instagram. The pre-research results with $56.5 \%$ of respondents who are generation $\mathrm{Z}$ shows $52.2 \%$ choosing visual and text as the most interesting advertising elements. In addition, $53.9 \%$ of respondents often see advertising through Instagram. The purpose of this descriptive quantitative research method is to analyze the audience response on public service advertisement (PSA) "JAGA DIRI, JAGA SESAMA DARI COVID-19" using the AISAS MODEL which consists of Attention, Interest, Search, Action, and Share dimensions. This research was conducted with survey data collection techniques to 108 respondents who had seen the PSA. The results of research indicate that the audience response on PSA has a high response for attention $83,7 \%$, interest $77,7 \%$ and action $83,8 \%$, while a low response for the search $61,5 \%$ and share $60,3 \%$. In other words, the Indonesian Ministry of Health through advertising messages on Instagram succeeded in getting the audience to take precautions against COVID-19 based on the highest results compared to all dimensions of the AISAS model, 83.8\%.
\end{abstract}

Keywords: Audience Response, Public Service Advertisement (PSA), COVID-19, AISAS Model, Instagram

\section{INTRODUCTION}

Communication is the process of delivering messages carried out by sources to audiences through certain media which can have certain effects on the hope of feedback. Communication aims to change the social, attitudes, opinions and behavior of audiences. Communication is done so that the public can know, understand and do something related to the message conveyed. Messages consist of verbal, non-verbal, oral, written or symbols that have a specific meaning and form. A form of message combining several of these elements is advertising. Basically, advertising is a message conveyed by a commercial company aimed at providing information, inviting and or reminding the public about the product or service brand through certain media. Advertising messages can be delivered precisely to the audience based on the media used. There are several types of media used, including newspapers, magazines, television, radio, outdoor (billboards, banners), and the internet (websites, social media).

Regardless of various types of advertising media used, the digital era has changed the way a person responds to a product or service brand on social media, because of the interactive communication between sources and audiences. In this way, the communication model known for a long time, namely AIDA (Attention, Interest, Desire, Action), has been transformed into AIDMA (Attention, Interest, Desire, Memory, Action) proposed by S. Roland Hall. In the end, Dentsu created a marketing communication model deriving from technological developments called AISAS (Attention, Interest, Search, Action, Share). This model can measure how customers have high or low involvement with a product. In addition, the AISAS concept can make a company or organization see that the audience or target audience is active in searching, finding and sharing information that has been obtained with others [1]. However, advertisements are often used by government institutions to convey messages of a non-commercial nature with the aim of providing audiences with information and education about certain issues, this 
type of advertisement is called Public Service Advertisements (PSA).

The latest global issue also occurring in Indonesia around March 2020 is COVID-19. COVID-19 is an infectious disease caused by a newly discovered type of coronavirus. The new virus and disease originated from an outbreak in Wuhan, China on December 2019. COVID-19 is now a pandemic occurring in many countries around the world. People can catch COVID-19 from other people who are infected with the virus. COVID-19 can be spread primarily from person to person through droplets from the nose or mouth coming out when an infected person coughs, sneezes or talks [2].

According to $\mathrm{WHO}$, ways to reduce the risk of being infected or spreading COVID-19 are frequent hand washing with clean running water and soap or using an alcohol-based antiseptic solution, known as a hand sanitizer. Other ways are maintaining a distance of at least 1 meter (physical distancing) and avoiding crowds and avoiding touching the eyes, nose and mouth, because they can become the entry point for the virus into the body [2]. Not only WHO but also the Ministry of Health of the Republic of Indonesia (KEMENKES RI) participated in handling the case. Several methods have been taken by the Republic of Indonesia's Ministry of Health, one of which is to inform the current situation of the development of COVID-19 and its prevention through online media, namely websites, social media such as Instagram, Facebook, Twitter and others [3].

Based on pre-research conducted in May 2020 on 115 respondents by researchers, $53.9 \%$ of respondents saw advertisements about COVID-19 through Instagram social media. This is also supported by the results showing that $54.8 \%$ of respondents are very active in viewing health advertisements closely related to this global issue. About $52.2 \%$ of respondents chose visuals and text as the most attractive elements to advertise COVID-19. Therefore, the researcher chose the object of research for the advertisement version of "Jaga Diri, Jaga Sesama from COVID-19" in the form of visuals and text and was first disseminated through the Indonesian Ministry of Health's Instagram at the beginning of the COVID-19 pandemic in Indonesia. The research was conducted to analyze descriptively how much the audience responds to PSA "Jaga Diri, Jaga Sesama from COVID-19" based on the AISAS communication model, namely Attention, Interest, Search, Action, and Share.

\section{LITERATURE REVIEW}

\subsection{Communication}

Communication according to Everett $M$. Rogers in Cangara [4] that communication is a process where an idea is transferred from the source to one or more recipients with the intention to change their behavior. Communication objectives, according to Effendy [5], consists of 4 (four): 1. Attitude, opinion, behavior and social change. To achieve this communication goal, communication occurs through a process that involves several elements of communication: source, message, channel, receiver, and response/feedback.

The sender or source of communication is the person or organization that has information to share with another person or group of people. The communication process begins when the source select words, symbols, pictures, and the like, to represent the message that will be delivered to the receivers. This process, known as encoding, involves putting thoughts, ideas, or information into a symbolic form. The sender's goal is to encode the message in such a way that it will be understood by the receiver. This means using words, signs, or symbols that are familiar to the target audience. The encoding process leads to development of a message containing the information or meaning the source hopes to convey. The message may be verbal or non verbal, oral or written, or symbolic. Messages must be put into a transmittable form that is appropriate to the channel of communication used [6].

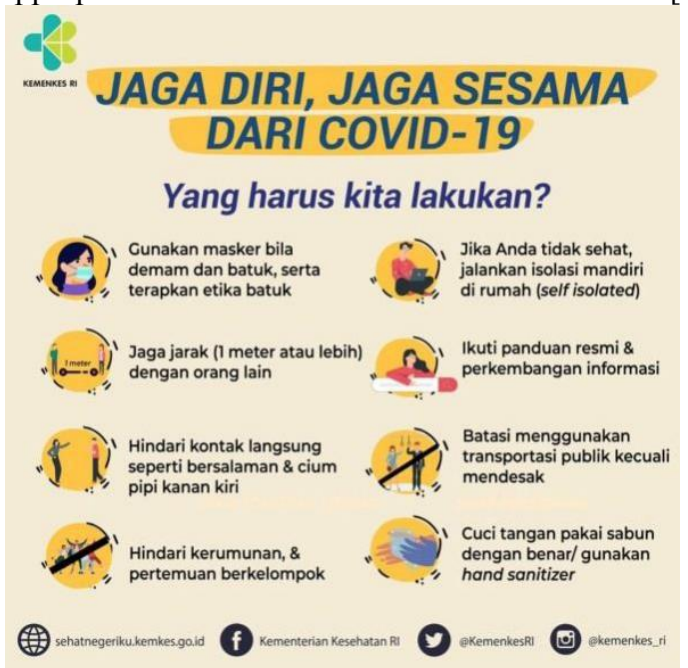

Figure 1. Public Service Advertisement "Jaga Diri, Jaga Sesama Dari COVID-19"

The channel is a method by which the communication travels from the source or sender to the receiver. At broadest level, communication channels consist of two types: nonpersonal and personal. Non personal channels of communication consist of two major types: printed and broadcast. Printed media include newspapers, magazines, direct mail, and billboards. Broadcast media include radio, and television. Internet has both nonpersonal and personal characteristics of communication. It has become a mass media vehicle at it is now an important source of information to most consumers and many advertising messages are delivered through various forms of online advertising including banner ads, paid search, and ads on social media sites. Personal channels involve direct communication between two or more persons and occur through interpersonal (face two face) contact or via other methods such as email or through social media [6]. 
The receiver is the person with whom the sender shares thoughts or information. Generally, receivers are the consumers in the target market or audience who read, hear, and/or see the marketer's message and decode it. Decoding is the process of transforming the sender's message back into thought. The receiver's set reactions after seeing, hearing, or reading the message is known as a response. Receiver responses can range from nonobservable actions such as storing information in memory to immediate action. Marketers are very interested in feedback, the part of the receiver's response that is communicated back to the sender. Feedback, which may take a variety of forms, closes the loop in the communications flow and lets the sender monitor how the intended message is being decoded and received [6]. Successful communication is accomplished when the marketer selects an appropriate source, develops an effective message, or appeal that is encoded properly, and then selects the channels or media that will best reach the target audience so that the message can be decoded and delivered effectively [6].

\subsection{Public service Advertisement (PSA)}

One of communication forms able to attract public attention is advertising. Advertising is a paid persuasive communication using mass media and an interactive media to reach audiences so that it connects identified sponsors to target audiences and provides information about goods, services, and ideas and interprets product features based on consumer needs and desires [7]. Basically, advertising aims to achieve something and create an impact. This impact can be in the form of a consumer's response to information or being persuaded to do something. The basic function of advertising is divided into three: (1) to identify the function of a product or place of the seller, (2) to provide information about a product, and (3) to persuade the audience to buy an item. There are five key components of advertising: strategy, message, media and evaluation [7].

Eight major types of advertising are: brand, retail, direct-response, business to business, institutional, nonprofit, public service advertising and specific advertising areas. Public service advertising provides messages on behalf of good cause [8]. Public service advertisements or announcements are promotional materials addressing the problems assumed to be of general concern to citizens at large. PSAs typically attempt to increase public awareness of such problems and their possible solutions, and in many instances also try to influence public beliefs, attitudes, and behaviors concerning them [8].

In order to develop more effective PSAs, O'Keefe and Reid [9] stressed the importance of integrating theoretical models into public service campaigns, recalling that "The more recent successful PSA campaigns have incorporated theoretical models of communication or persuasion into their development". In addition to the importance of incorporating theoretical models into PSAs for a better understanding on the psychological processes of target audiences, it is also critical to understand the role of individual differences in the effects of PSAs on the information process for those messages. LaBarbera, Weingard, and Yorkston indicated that individual psychological differences are becoming a more viable foundation for developing advertising messages aimed at each target market [9].

\subsection{Social Media Instagram}

Based on Kaplan and Haenlein, social media have been defined as "a group of Internet-based applications that build on the ideological and technological foundations of web 2.0 and that allow the creation and exchange of usergenerated content" [7]. Many variations and types of social media exist. Facebook (a social network), Snapchat (an instant photo messaging application), Instagram (a photosharing application), Twitter (a microblogging application), LinkedIn (a business-and employment- oriented social networking service), GoogleC (an interest- based social network), and Pinterest (a "catalog of ideas" or photosharing website) represent different types of social media, each with unique architectures, cultures, and norms [10].

Two defining characteristics lead to four categories of social media [10]:

1. Relationship represents social media platforms that are profile based and consist mostly of customized messages; this category includes platforms such as Facebook and LinkedIn.

2. Self-media platforms are also profile based but offer people the chance to manage their own social media communication channels. A typical example is Twitter.

3. Creative outlet platforms are content based and allow users to share their interests and creativity, for example, YouTube and Instagram.

4. Finally, collaboration platforms are also content based but allow people to ask questions, get advice, or find the most interesting news and content of the day.

Instagram is an online mobile social-networking service that enables users to take photos and videos and share them on a variety of social networking platforms. Instagram was only launched in 2010 , but this photo- and video-sharing social-networking service has grown tremendously via its mobile app. Instagram users follow other users, like and comment on their photos, and share them [11]. Instagram can be seen as the context for social media advertising; the content can be maximized to package advertising messages in the form of attractive visuals and text through the features of feeds, captions, hashtags, comments, shares, and others. Advertising messages involve Instagram as an advertising medium and audiences as message recipients who can like, comment and share advertisements as a source of messages to other audiences. Engagement with a medium, in this case is Instagram as a type of social media advertising, can be seen as an essential context characteristic that drives responses to advertising [10]. 


\subsection{AISAS Model}

The most important aspect of developing communication programs involves understanding the response process the receiver may go through in moving toward a specific behavior such as knowing (cognitive stage), liking (affective stage) and doing what is conveyed in the advertising message (behavioral stage). The AISAS model is a part of the development of AIDA (Attention, Interest, Desire, Action) model into AIDMA (Attention, Interest, Desire, Memory, Action) as proposed by $\mathrm{S}$. Roland Hall in order to present the response process from the audience. When a high-involvement product is needed, the customer will do a deeper search than low-involvement product. Therefore, Dentsu [1] suggests a marketing communication model obtained from technological developments, which is named the AISAS model (Attention $\rightarrow$ Interest $\rightarrow$ Search $\rightarrow$ Action $\rightarrow$ Share).

Based on this description, basically, the AISAS model is applied to commercial advertising messages in the development of a marketing communication program. However, the researchers tried to apply the AISAS model to public service advertising messages. The difference here lies on the Action stage on. If the message is a commercial advertisement, the audience purchases a product or uses a service. Meanwhile if it is applied to a public service advertisement message, the audience carries out an advertising message in the form of an appeal from government institutions. Through the AISAS concept, the company in this study is a government institution seeing the audience as an active person, who can search for information and share information that has been obtained with others. The concept of AISAS consists of:

a. Attention

Advertising messages must attract the attention of the audience; therefore advertising messages require the use of colors, layouts, fonts and the photos/illustrations displayed. The main thing really needing to be considered is that the attention of the audience must be obtained.

b. Interest

After the attention to advertising messages has been successfully carried out, the problem faced is whether or not audience has more interest and curiosity. For this reason, audience must be stimulated in order to want to read and follow the advertising messages delivered.

c. Search

Search is an advantage for audience, because with the search engine, before making a decision, audience will try to find as much information as possible through search engines. In this case, such as reviews on news portals, posts on blogs, other websites, and all information will appear clearly in search engines, this is what helps consumers to make decisions.

d. Action

Action is audience action; at this stage the real experience is created. Public Service Advertisement messages aims to inform as well as educate the public whether or not the government institutions' appeals can be carried out by the public.

e. Share

Share is the result after the audience has experienced all the experiences as appealed by the institution, the audience will share their experience with others through social media, email, chat, blogs, mailists, online forums, and others. Thus, good or bad experiences will spread to many people easily.

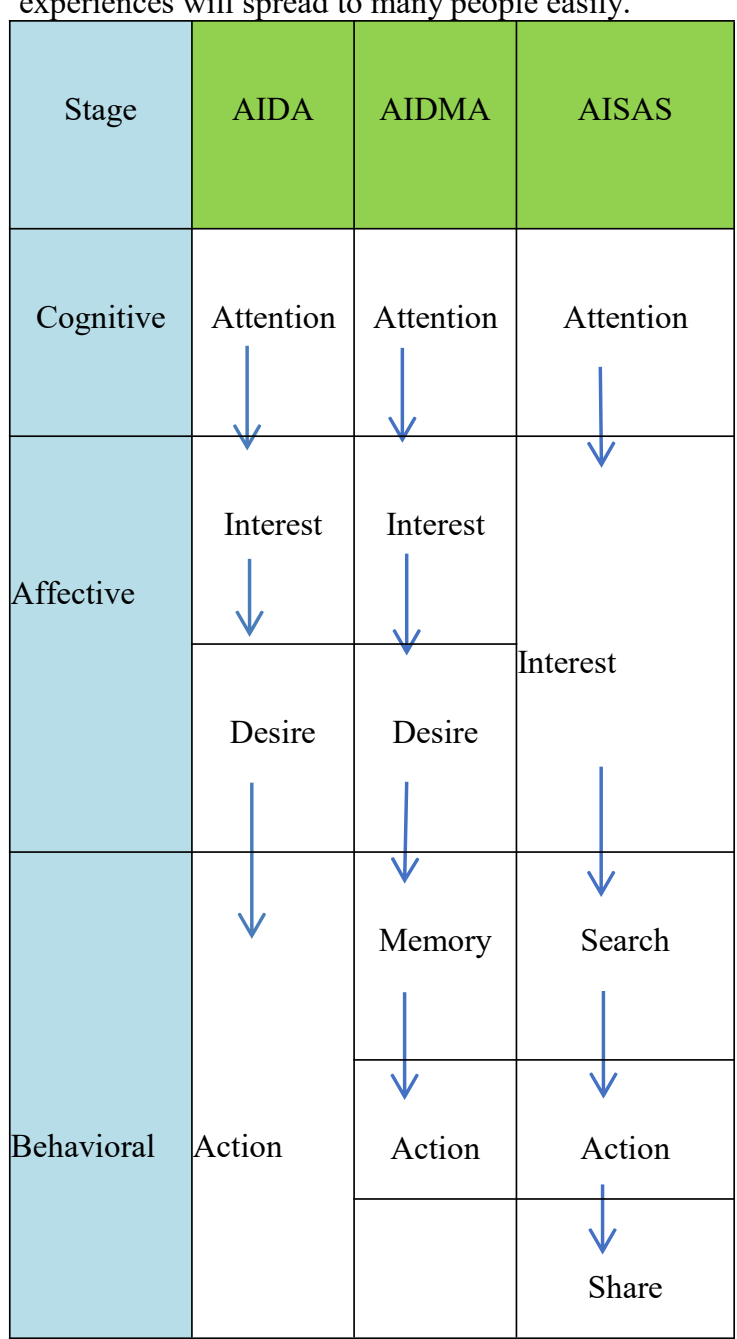

Figure 2. Comparison between AIDA, AIDMA and AISAS

In elements A and I of the AISAS model, government institutions are expected to be able to create communication that can attract public attention to the source. The advertising message obtained by the audience is an important factor in moving to the next element, that is, where the audience is more active in the S, A and S elements in the AISAS model. The previous AIDMA model was not yet fully applicable in the current internet era because the audience searched for references first. Either through search engines, websites, online forums or certain social media. They will ask questions, and wait for answers in the form of recommendations. Furthermore, the audience will share the information obtained through advertising messages to other audiences. The audience will 
respond positively or negatively to other audiences and the cycle will repeat. The right model to describe response, attitude and behavior of audiences in the internet era is the AISAS model [12].

\section{METHODS}

Paradigm used in this study is positivism. A positive view of social science, according to Neuman, combines deductive logic and exact empirical observation through individual behavior. Furthermore, it positively aims to discover and confirm a set of probabilistic causal laws that can be used to predict general patterns of human activity [13]. The research method used in this study was quantitative one. Quantitative characteristic, the researcher began the study with hypothesis testing. The concepts taken are in the form of clear and measurable variables, taken before preparation, before data collection and each measurement meets the standards set [13].

The study used survey as data collection technique through distributing questionnaire to 108 respondents who have ever seen Instagram Advertising Jaga Diri, Jaga Sesama from COVID-19 version on Instagram @kemenkes_ri with an error level of $5 \%$. The population was homogeneous because the source elements have the same character and need to have sample, as stated in Miles and Huberman [14] The type of sample is non-probability random sampling, meaning that every population member does not have the same chance to be chosen as sample. It is based on the same criteria, the follower@kemenkes_ri and having ever seen the Kemenkes RI Instagram Advertising Jaga Diri, Jaga Sesama from the COVID-19 version. This study used univariate variable, audience response is an independent variable $(\mathrm{X})$ measured based on attention, interest, search, action, and share dimensions. The data analysis technique used was descriptive statistics to get tabulated form, by entering all the data then processed descriptive statistics which were used to report the results in the form of frequency distribution and percentage (\%) of each item.

\section{RESULTS AND DISCUSSIONS}

Based on the results of a survey conducted on 108 respondents on June 2020, at most 73 people were female, 58 people aged 23 to 28 years and 35 people are college students. Instagram users in Indonesia are dominated by productive age (18-34 years), it can be said that the millennial generation is 25 million users. This generation is one of the productive and active generations in the digital era. Meanwhile, female Instagram users (63\%) dominate more than male users do because they tend to use Instagram actively everyday [15].
Table 1. Respondents Data

\begin{tabular}{llc}
\hline No & Respondent & Number \\
\hline 1 & Gender & 35 \\
\cline { 2 - 3 } & Male & 73 \\
\cline { 2 - 3 } & Female & \\
\hline 2 & Age (year) & 37 \\
\cline { 2 - 3 } & $17-22$ & 58 \\
\hline $23-28$ & 9 \\
\cline { 2 - 3 } & $29-34$ & 2 \\
\hline $35-40$ & 2 \\
\hline 3 & P 40 & 1 \\
\hline & Profession & 35 \\
\cline { 2 - 3 } & Student & 25 \\
\cline { 2 - 3 } & College Student & 6 \\
\cline { 2 - 3 } & Private Employees & 2 \\
\cline { 2 - 3 } & Bovernment Employees & 34 \\
\cline { 2 - 3 } & Others & \\
\hline
\end{tabular}

Source: Processed Research Data, 2020

Based on the following table, on the attention dimension, total score 1810 and $83.7 \%$, belonging to very high category, indicating that the Jaga Diri, Jaga Sesama From COVID-19 version of the Public Service Advertisements of the Indonesian Ministry of Health on Instagram attracts the attention of the public. The ad uses visual elements and text in the form of infographics. The advertisement consists of the logo of the Indonesian Ministry of Health in green, beige background color, blue in the headline and sub-headline text, and black in the bodycopy text. There is an orange color highlighting the text and infographic background. The use of attractive and not excessive colors makes the audience seeing the entire ads comfortably. The ads layout seems to be balanced between logos, text and infographics. The type and the size of the letters used are clear so that the text is readable to the audience. The illustrations contained in the bodycopy represent the text so that they are easily understood by the audience. The baseline in the form of other Ministry of Health information on the Ministry of Health's website, social media Twitter, Facebook and the Ministry of Health's Instagram is also clearly visible.

Table 2. Audience Response Statistics Data based on AISAS Model

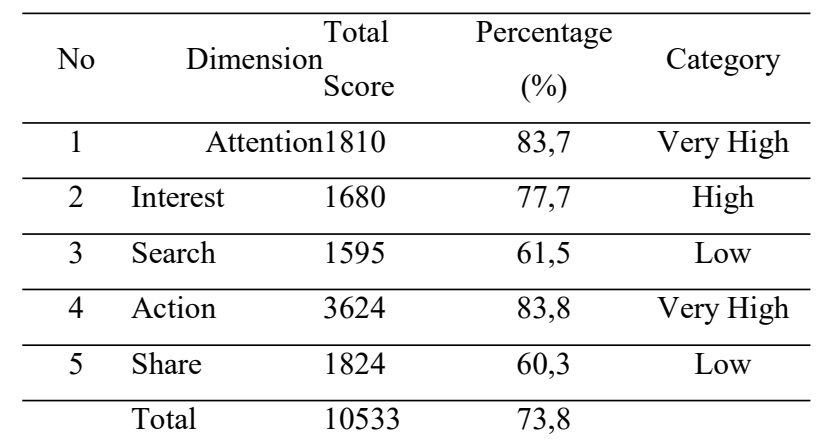

Source: Processed Research Data, 2020 
In the interest dimension, the result obtained is total score 1680 and $77.7 \%$, belonging to high category, indicating that after the Jaga Diri version of the Indonesian Ministry of Health's Public Service Ads, Jaga Sesama From COVID-19 on Instagram attracted attention through previous advertising elements, the audience had more curiosity and interest in reading the whole advertising message, that is, the Indonesian Ministry of Health's appealing to prevent themselves from COVID-19, including 1) using a mask when fever and coughing and applying cough etiquette, 2 ) maintaining distance (1 meter or more) with other people, 3 ) avoiding contact direct such as shaking hands and kissing right and left cheeks, 4) avoiding crowds and group meetings, 5) undergoing selfisolation at home if sick, 6) following official guidelines and information development, 7) limiting the use of public transportation unless in urgency, and 8) washing hands use soap properly / using a hand sanitizer.

In the search dimension, the result obtained total score of 1595 and $61.5 \%$, belonging to low category, indicating that after more curiosity to read the entire message of the Indonesian Ministry of Health's version of Jaga Diri, Jaga Sesama Dari COVID-19 Public Service Ads on Instagram, the public is trying to find general information about COVID- 19 by asking directly via direct message, Instagram comment column@ @kemenkes_ri, Instagram account of friends who tagged and mentioned the ads. It can be said that the advertising message in the form of COVID-19 prevention information by the Indonesian Ministry of Health on Instagram is clearly accepted by the public. Meanwhile, some audiences are still trying to find specific information about COVID-19 and its prevention through other sources. This shows that the information sought about COVID-19 and its prevention varies according to needs before people make decisions. This implies that the information sought about COVID-19 and its prevention varies according to needs before the public makes a decision.

In the action dimension, the result obtained a total score of 3624 or $83.8 \%$ after seeking general or specific information about COVID-19 and its prevention, the audience should take self-prevention from COVID-19, according to the recommendations given by the Indonesian Ministry of Health, among others 1) wearing mask if you have a fever and cough and applying cough etiquette, 2) maintaining a distance (1 meter or more) from other people, 3) avoiding direct contact such as shaking hands and kissing right and left cheeks, 4) avoiding crowds and group meetings, 5) undergoing self-isolation at home if sick, 6) following official guidelines and information development, 7) limiting the use of public transportation unless in urgent case, and 8) washing hands properly with soap / using hand sanitizers. This shows that the majority audience is doing self-prevention from Covid-19 in accordance with recommendations from the Indonesian Ministry of Health.

In the share dimension, the total score was 1824 or $60.3 \%$ after the audience had prevented COVID-19 according to the recommendations given by the Indonesian
Ministry of Health through PSA Jaga Diri, Jaga Sesama Dari COVID-19 at Instagram@kemenkes_ri. The share dimension gets the lowest results compared with other dimensions. This indicates that there is a high probability that audiences have received advertising messages with the same information through other sources than social media such as Instagram, online news portals, television, radio, outdoor media, and others. Even so, some audiences still consider that it is important to share information about self-prevention from COVID-19 and experiences after doing it as recommended to family, friends and colleagues.

\section{CONCLUSION}

Based on the results and previous discussion about the Analysis of Audience Response on Public Service Advertisement about Covid-19 in Instagram according to AISAS Model through questionnaires distributed to 108 respondents, it can be concluded that the variable PSA Jaga Diri, Jaga Sesama Dari COVID-19 has a 83.7\% score for attention dimension, $77.7 \%$ for interest dimension, $61.5 \%$ for search dimension, $83.8 \%$ for action dimension and $60.3 \%$ for share dimension. This indicates that the Public Service Advertisement version of the Public Service Ads version of the Jaga Diri, Jaga Sesama Dari COVID-19 generates a high response to the dimensions of attention, interest and action, but a low response to the dimension of search and share. In other words, the Indonesian Ministry of Health through an advertising message on Instagram successfully invites the audience to guard against COVID-19 based on the highest results in action dimension $(83.8 \%)$ compared with all the dimensions of the AISAS model

\section{REFERENCES}

[1] K. Sugiyama and T. Andree, The Dentsu Way, New York: McGraw Hill, 2011.

[2] https://www.who.int/indonesia/news/novelcoronavirus/qa-for-public

[3] https://covid19.kemkes.go.id/category/situationemerging-infection/info-corona-virus/\#.

Xy_LUjUxX7A

[4] Cangara Hafied. Pengantar Ilmu Komunikasi. Jakarta:Raja Grafindo Persada, 2008

[5] Effendy, Uchjana Onong. Ilmu Komunikasi Teori dan Praktek. Bandung: PT. Remaja Rosdakarya, 2004.

[6] Belch. Goerge E and Belch. Michel.: Advertising \& Promotion: An Integrated Marketing Communications Perspective, Eleventh Edition. New York, NY, USA: McGraw-Hill Education, 2012 
[7] Moriarty. Sandra, Mitchell. Nancy and Wells. William.: Advertising \& IMC: Principles and Practice, Tenth Edition. New York, NY, USA: McGraw-Hill Education, 2015

[8] Garrett J. O'Keefe \& Kathaleen Reid (1990) The Uses and Efiects of Public Service Advertising, Public Relations Research Annual, 2:1-4, 67-91, DOI: 10.1207/s1532754xjprr0201-4_3

[9] Park Meungguk, Brian A. Turner, Donna L. Pastore (2008) Effective Public Service Advertisements to Attract Volunteers for the Special Olympics: An Elaboration Likelihood Perspective, Sport Management Review Volume 11, Issue 2, September 2008, Pages 165-192, https://doi.org/10.1016/S14413523(08)70108-6

[10] Hilde A. M. Voorveld, Guda van Noort, Daniël G. Muntinga \& Fred Bronner (2018): Engagement with Social Media and Social Media Advertising: The Differentiating Role of Platform Type, Journal of Advertising, DOI: 10.1080/00913367.2017.1405754
[11] Quesenbery, Keith A. Social Media Strategy. Marketing, Advertising, and Public Relations In The Consumer Relation. Second Edition. Rowman and Littlefield. United Kingdom, 2019.

[12] Pelawi, Yunus Natanael, Irwansyah \& Monika Pretty Aprilia (2019) Implementation of Marketing Communication Strategy in Attention, Interest, Search, Action and Share (AISAS) Model through Vlog, IEEE 4th International Conference on Computer and Communication Systems (ICCCS), 23-25 Feb.2019, 10.1109/CCOMS.2019.8821721

[13] W. L. Neumann, Social Research Methods: Qualitative and Quantitative Approachs, United Kingdom: Pearson Education, 2013.

[14] Punch, Keith F.: Introduction to Social Research Quantitative and Qualitative Approach. London: Sage Publications, Ltd, 1998

[15] https://www.goodnewsfromindonesia.id/2020/06/1 4/pengguna-instagram-di-indonesia-didominasi-wanitadan-generasi-milenial 